\title{
Effects of Process Variables in Semi-continuous Cultivation of Chlorella Minutissima on the Biomass Composition
}

Geronimo Virginio Tagliaferro ( $\boldsymbol{\sim}$ tagliaferro@usp.br)

Universidade de Sao Paulo Escola de Engenheria de Lorena https://orcid.org/0000-0003-1988-5681

\section{Wallyson Ribeiro dos Santos}

Universidade de Sao Paulo Escola de Engenheria de Lorena https://orcid.org/0000-0002-5878-056X Júlio Cesar dos Santos

Universidade de Sao Paulo Escola de Engenheria de Lorena https://orcid.org/0000-0001-6192-6155

\section{Priscila Pereira}

Universidade de Sao Paulo Escola de Engenheria de Lorena https://orcid.org/0000-0001-5411-1847

\section{Carolina Roma}

Universidade de Sao Paulo Escola de Engenheria de Lorena https://orcid.org/0000-0003-3032-3516

\section{Messias Borges Silva}

Universidade de Sao Paulo Escola de Engenheria de Lorena https://orcid.org/0000-0002-8656-0791

Daniela H. P. Guimarães

Universidade de Sao Paulo Escola de Engenheria de Lorena https://orcid.org/0000-0002-4797-1168

\section{Short Report}

Keywords: Biomass, Chlorella minutissima, Landfill leachate, Airlift

Posted Date: August 23rd, 2021

DOl: https://doi.org/10.21203/rs.3.rs-694073/v1

License: (c) (i) This work is licensed under a Creative Commons Attribution 4.0 International License.

Read Full License 
Effects of process variables in semi-continuous cultivation of Chlorella minutissima on the biomass composition

Wallyson Ribeiro dos Santos, Geronimo Virginio Tagliaferro*, Júlio César dos Santos, Priscila Pereira, Carolina Roma, Messias Borges Silva, Daniela Helena Pelegrine Guimarães

Chemical Engineering Department, Engineering School of Lorena, University of São Paulo, Lorena, SP, Brazil.

\section{$\underline{\text { ORCID }}$}

Wallyson Ribeiro dos Santos: 0000-0002-5878-056X

Geronimo Virginio Tagliaferro: 0000-0003-1988-5681

Júlio César dos Santos: 0000-0001-6192-6155

Priscila Pereira: 0000-0001-5411-1847

Carolina Roma: 0000-0003-3032-3516

Messias Borges Silva: 000-0002-8656-0791

Daniela H.P. Guimarães: 0000-0002-4797-1168

* Corresponding author 


\begin{abstract}
The biomass composition of Chlorella minutissima $26 a$ was evaluated in different conditions for the microalgae cultured in landfill leachate in airlift photobioreactor operated in semi-continuous mode. The effects of the following factors in cells composition were evaluated: landfill leachate concentration (LC), $\mathrm{CO}_{2}$ percentual flow added in the gas stream (GP), aeration flow in the reactor (AF) and feed flowrate (FR). A Taguchi $\mathrm{L}_{9}$ orthogonal arrangement was used to evaluate the effects of those four factors on the following response variables: Biomass Productivity (BP), Lipid Productivity (LP), Carbohydrate Productivity (CP) and Proteins Productivity (PP). Results showed that the microalgae had high selectivity to produce proteins, reaching a maximum content of $69,60 \%$ in the following conditions: LC: $10 \%$, GP: null, AF: 0,30 vvm and FR: $0.9 \mu \max v v m$. The highest contents of lipid and carbohydrate were $17.4 \%$ (LC: $15 \%$, GP: null, AF: 0,45 vvm and FR: $0.7 \mu$ max vvm) and 11.6\% (LC: 10\%, GP: 15\%, AF: 0,15 vvm and FR: $0.7 \mu$ max vvm.), respectively, both values achieved at the two experiment with the highest values of specific growth rate $\left(0.44 \mathrm{~d}^{-1}\right.$ and $0.47 \mathrm{~d}^{-1}$, respectively). Statistical analysis showed LC was the most influential factor in the cell chemical composition, being significant $(\mathrm{p}<0,1)$ in the productivity of lipids, proteins and carbohydrates, with high values observed using between 5 and $10 \%$ of LC in the medium. GP did not show significance for any response studied, while the variables AF and FR showed significance in the productivity of proteins.
\end{abstract}

Keywords Biomass Chlorella minutissima Landfill leachate Airlift

Declarations not applicable

Funding São Paulo research Foundation (FAPESP, Brazil): grants 2014/03244-0 and 2016/23416-6.

Conflict of Interest The authors declare that they have no conflict of interest.

\title{
Graphic Abstract
}

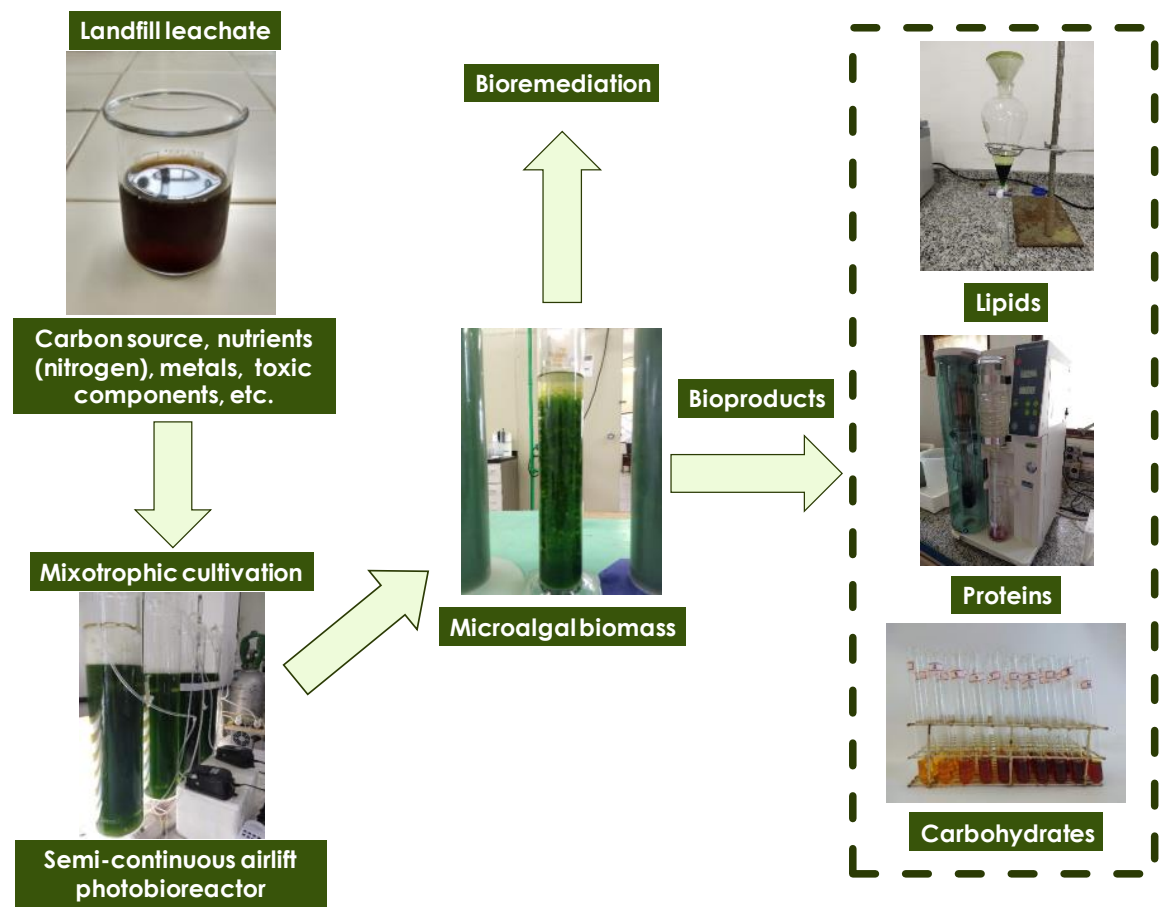




\section{Statement of Novelty}

This manuscript is about the use of an airlift photobioreactor operated in semi-continuous mode for cultivation of microalgae Chlorella minutissima . The effects of leachate concentration, percentage of $\mathrm{CO}_{2}$ added to the gas stream, aeration flow and feed flow on microalgae composition and biomass productivity were evaluated. Studies dealing with the semi-continuous cultivation of microalgae in air transport photobioreactors are scarce in the literature, especially considering the use of Chlorella minutissima. Furthermore, the influence of leachate concentration is not fully understood, with some conflicting data on its effect on biomass composition. Thus, our manuscript contributes to increase knowledge about microalgae cultivation and includes a proposal for semi-continuous mixotrophic cultivation in a high-yield system with advantages such as simple construction, adequate mixing conditions and efficient exposure of cells to light. In addition, our manuscript helps to understand the significance of each factor applied to cultivation by using Taguchi's method and application of analysis of variance (ANOVA).

\section{Introduction}

In recent years, microalgae have shown themselves to be highly promising raw materials for the production of various bioproducts, such as food supplements, biofuels, pigments, antioxidants, among others. Microalgal biomass contains various compounds such as lipids, carbohydrates, pigments, etc., which can be modulated by changing cultivation conditions $[1,2]$.

Moreover, the search for new resources of energy capable of meeting global demand and, simultaneously, replacing fossil fuels, has increasing annually [3]. Actually, the urgency of combating global warming drives several research works around the planet in order to reduce the amount of polluting gases in the atmosphere, whether in the development of biofuels or in the bio-fixation of gases by plants and microorganisms $[4,5]$.

The concept of biorefinery can be effectively applied to the use of microalgal biomass in industrial processes due to the possibility of production of different interesting compounds or biofuels, also including the $\mathrm{CO}_{2}$ fixation by those microorganisms. In particular, the microalgae of the genus Chlorella can be easily produced on a large scale and consumed as a food supplement [6,7].

According to Singh, Liu, Sharma and Apandi et al. [7,8], such microorganisms are also able to grow rapidly in the most adverse aquatic environments, such as wastewater, contaminated water and brackish water, with the ability of accumulating large lipids that can be converted into biodiesel, or carbohydrates that can be converted into bioethanol, or even produce added value compounds such as pigments and drugs.

The interest in use of microalgae as raw material to obtain bioproducts is also increasing due to great advances in bio-system engineering, although there are still important gaps, as low biomass concentration in the bioreactor and high costs of formulating a synthetic culture medium. Aiming to overcome those drawbacks, studies have been directed to evaluation of nutrients concentration, aeration flow, options of operation mode of production systems (e.g. continuous or discontinuous), and new alternatives of environmentally sustainable processes [9-14]. 
Actually, the cultivation of microalgae is an easy process with great applicability; however, special attention must be given to the influence of environmental factors. Temperature, $\mathrm{pH}$, lighting and availability of carbon source, aeration flow and feed flowrate are some of the factors that can influence the concentration of microalgae biomass in the process. Therefore, those factors must be carefully controlled so that the biomass produced has the desired quality [15-17].

The construction of reactors that enable the cultivation of microalgae on a large scale allowing greater control over operating conditions stands out as an important challenge. Indeed, the high costs of construction and operability of photobioreactors are limiting factors for their commercial use, by not presenting the conditions to support large-scale cultivation in an economically viable manner [18-20]. On the other hand, airlift photobioreactors have been studied considering their higher productivity in biomass and due to advantages as low possibility of contamination, better control of the gas-liquid mass transfer rate, greater penetration and exposure to light even with the increase in cell density during cultivation, high productivity per area and low cost of harvesting biomass [14,21-23].

Although microalgae have high lipid productivity, their large-scale cultivation demands a high content of nutrients. In this sense, different types of effluents have been tested as source of water and nutrients for the cultivation of microalgae, as wastewater or landfill leachate, which can reduce production costs [3,24,25]. The use of effluents for microalgae cultivation can also improve the energy balance and reduce environmental impacts associated with their disposal in bodies of water without prior treatment. With this principle, the use of microalgae for the treatment of effluents is a viable and low-cost alternative that can results in great reduction in the effluent pollutant power [26-29].

In present work, leachate was used as nutrient source and, thus, the evaluated cultivation option can be an interesting for both: use the leachate as nutrient sources to produce valuable biomass and use of the microalgae as a method for the effluent treatment.

Thus, the main objective of this work was to evaluate the production and composition of biomass in airlift bioreactor operated in semi-continuous mode to cultivate the microalgae Chlorella minutissima. The effects of leachate level, $\mathrm{CO}_{2}$ percentage added in the gaseous stream, aeration flow in the reactor, and flowrate of the feed stream, were evaluated in the cultivation performance. The experiments were carried out according to an orthogonal arrangement of Taguchi L9. Cell composition in the different studied conditions in terms of the contents of lipids, proteins, and carbohydrates, was evaluated. The semi-continuous mode was chosen due to its advantages, such as maintenance of the logarithmic phase growth, absence of shading effect caused by high cell density, possibility of constant replacement of fresh culture medium, providing increased productivity [30].

\section{Materials and methods}

\section{Microalgae specie, maintenance and inoculum preparation}

The microalgae Chlorella minutissima $26 a$ was obtained from the Marine Cultures Collection of the Oceanographic Institute at the University of São Paulo (São Paulo, SP, Brazil), located in Cabo Frio city (Rio de Janeiro, Brazil). The strain was stored in a wooden incubator equipped with a photoperiod, 
controlled by a timer. The maintenance of this cell bank was carried out by replicating the cells in Erlenmeyer flasks $(125 \mathrm{~mL}$ ), with $12 \mathrm{~h}$ (light/dark) of photoperiod and an average luminance of $4.8 \mathrm{klux}$ (Fig. 1a). The Guillard medium $\mathrm{f} / 2$ [31] was used to grow the strain, with all the reagents used in the preparation of analytical standard grade. The sub-cultures were done every 15 days, in the proportion of 10 $\mathrm{mL}$ of previous culture to $90 \mathrm{~mL}$ of new culture medium, and the flasks were manually shaken once a day. The inoculum was grown in a bubble tubular photobioreactor $(2.0 \mathrm{~L})$ made up of transparent polyethylene terephthalate (PET) (Fig. 1b), following the same proportions as the used to the growth in Erlenmeyer flasks. In order to avoid contamination of the inoculum, all containers used were previously chlorinated and neutralized with Sodium Thiosulfate $\left(\mathrm{Na}_{2} \mathrm{~S}_{2} \mathrm{O}_{3}\right)$ [32]. Innoculum growth was carried out in a batch process with aeration of $0.24 \mathrm{vvm}$, controlled by means of absorbance readings (at $680 \mathrm{~nm}$ ) until reaching the value of 1.500 . This value of absorbance was chosen due to the need to standardize cell concentration which served as a starting point for cultivation in airlift reactors.

\section{Microalgae cultivation in bioreactor}

Microalgae growth was carried out in a bench-top airlift photobioreactor with a working volume of 4 liters, continuously illuminated of with luminance of $4.8 \mathrm{klux}$, and placed in a laboratory with the room temperature kept at $30{ }^{\circ} \mathrm{C}$. The photobioreactor (Fig. 1c) size was based on that used by Tagliaferro et al. [21]. Reactor was charged with inoculum suspension $(10 \% \mathrm{v} / \mathrm{v})$ and culture medium. The culture medium consisted of distilled water, landfill leachate (concentrations according to experimental design, as section 2.2.2) and salt $\left(20 \mathrm{~g} . \mathrm{L}^{-1}, \mathrm{NaCl}\right)$. The bioreactor was aerated at flowrate values according to experimental design. Aeration had a percentual volume of $\mathrm{CO}_{2}$ flow, also according to the experimental design.

\section{Determination of the maximum specific growth rate ( $\mu$ max)}

At first, cultivations were carried out in a batch regime until their absorbance reached a value of 0.75 (680 $\mathrm{nm})$, so that the calculation of the maximum specific growth rate $\left(\mu_{\max }\right)$ was performed. To determine the value of the maximum specific growth rate, the graph of dry biomass was plotted on a logarithmic scale as a function of time and the slope of the formed line was calculated at linear region.

\section{Microalgae cultivation in semi-continuous mode}

For semi-continuous mode cultivation, firstly the system was operated as a batch (section 2.2.1), until the absorbance reaches $0.75(680 \mathrm{~nm})$. Then, one third of the working volume of medium was removed from the reactor and fresh medium was added at a feed flowrate (FR, L/h) calculated as Equation 1, using a peristaltic pump. The same volume was removed from the reactor each $8 \mathrm{~h}$, with continuous feeding at FR. Each removed volume was used as sample for analysis of biomass composition. The total time of the cultivation in each experimental condition was 21 days. 


$$
F R=V / t
$$

Where:

$\mathrm{V}=$ working volume of the bioreactor $(4 \mathrm{~L})$.

$\mathrm{t}=$ Total time of the experiment (21 days).

The influence of the following factors in the process was evaluated: landfill leachate concentration (LC) $(5 \%, 10 \%$ and $15 \% \mathrm{v} / \mathrm{v}), \mathrm{CO}_{2}$ percentage added to the air in in the aeration flow (GP) $(0 \%, 10 \%$ and $15 \%$ of the $\mathrm{AF})$, and reactor aeration flow $(\mathrm{AF})(0.15,0.30$ and $0.45 \mathrm{vvm})$. Experiments were performed according to a Taguchi $\mathrm{L} 9$ matrix. The ranges of $\mathrm{CO}_{2}$ percentage and aeration flow in the reactor were based on the work of Zhao et al. [25]. The software Minitab 16 (Minitab LLC, State College, Pennsylvania, USA) was used for statistical analysis of the results. Response variables included the productivities in biomass, lipids, proteins and carbohydrate.

Fig. 1 Stages of cultivation of the microalgae Chlorella minutissima 26a: cell bank (a), inoculum (b) and airlift photobioreactor (c).

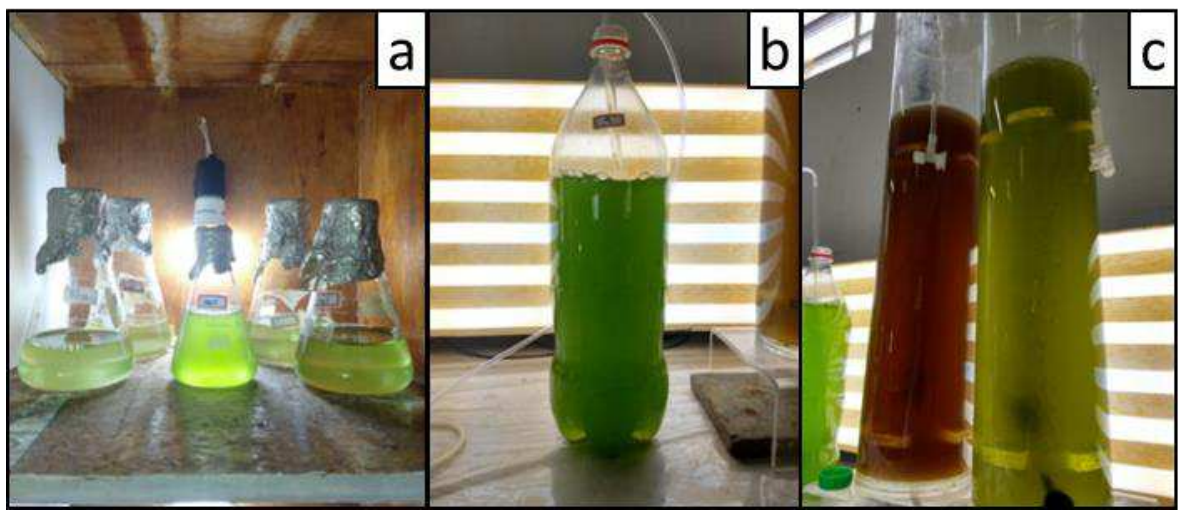

\section{Biomass harvesting}

The biomass was separated from the culture medium by flocculation, using $0.15 \mathrm{M}$ aluminum sulfate as the flocculating agent [33]. After flocculation, the biomass was subjected to the vacuum filtration process with quantitative filter paper (15 $\mu \mathrm{m})$, using a system equipped with Buchner Funnel and a vacuum pump (131 - Type 2 VC, Prismatec). After separation, the biomass was oven dried (LT1000, Terroni) at $60^{\circ} \mathrm{C}$ for 24 hours.

\section{Analytical methods}

The humidity was determined by weighing the biomass before and after drying in an oven at $105{ }^{\circ} \mathrm{C}$, according to the AOAC 96811 method [34].

Total lipids (L(\%)) were extracted by following the procedure proposed by Bligh and Dyer [35], adapted as following described. The biomass was disposed of in a $125 \mathrm{~mL}$ Erlenmeyer and its humidity was adjusted until $64 \%$, by adding distilled water; this humidity value was considered ideal by Zorn et al. [36]. Then, the 
Erlenmeyer was transferred to an ultrasonic bath (Sppencer, USC-800) for 15 minutes. At the end of this period, $9.4 \mathrm{ml}$ of chloroform and $10.2 \mathrm{ml}$ of methanol were added for each $1 \mathrm{~g}$ of biomass and the solution was homogenized. The system then returned to the ultrasound bath (Hielscher Ultrassound Technology, UP 200S) for 35 minutes. After the ultrasound process was completed, $3.4 \mathrm{~mL}$ of distilled water was added to the solution to make the system biphasic and to facilitate the removal of lipids. After standing for 12 hours for complete phase separation, the nonpolar phase was collected in a sample glass previously dried and weighed. The sample glass was placed in the oven at $60^{\circ} \mathrm{C}$ for 24 hours for the complete evaporation of the chloroform. The lipid content $(\mathrm{L}(\%))$ was determined according to Eq. 2 which presents the ratio between the Mass of lipids ( $\left.\mathrm{M}_{\text {lipid }}\right)$ produced and the Mass of biomass $\left(\mathrm{M}_{\text {biomass }}\right.$ used in the analysis.

$$
\mathrm{L}(\%)=\left(\mathrm{M}_{\text {lipid }} / \mathrm{M}_{\text {biomass }}\right) \times 100
$$

Crude protein content $(\mathrm{P}(\%))$ was estimated according to Guimarães and Lanfer-Marquez [37], considering "protein content $=$ nitrogen concentration $\times 5.75$ ", with the total nitrogen concentration measured by the Kjeldahl method (1980) [34].

The carbohydrate content $(\mathrm{C}(\%))$ in microalgae biomass was determined following the method of Moxley and Hang [38] and the DNS method [39] was employed as a standard protocol to determine the amount of reducing sugar.

All analyses, referring to the composition of microalgae biomass, were performed in duplicate.

For the determination of lipid productivity (LP), protein productivity (PP) and carbohydrate productivity (CP), Eq. 3 and Eq. 4 were used, respectively.

$$
\begin{aligned}
& \text { Productivity }\left(\mathrm{mg} \cdot \mathrm{L}^{-1} \cdot \mathrm{d}^{-1}\right)=(\mathrm{PB} \times \mathrm{G}(\%)) / 100 \\
& \operatorname{PB}\left(\mathrm{mg} \cdot \mathrm{L}^{-1} \cdot \mathrm{d}^{-1}\right)=\mathrm{M}_{\text {biomass }} /\left(\mathrm{V}_{\text {reactor }} \times \Delta \mathrm{t}_{(\text {days })}\right)
\end{aligned}
$$

In which $\mathrm{PB}$ is the volumetric productivity in biomass, $\mathrm{V}_{\text {reactor }}$ is the reactor volume, $\Delta \mathrm{t}$ is the time variation and $\mathrm{G}$ was lipid, protein or carbohydrate content.

The determination of ash content (A\%) was carried out based on the adaptation of the methodology proposed by Van Wychen and Laurens [40], in which the calcination of the samples is used in a muffle furnace. The analysis started with the heating of empty porcelain crucibles and the application of a heating ramp from $50^{\circ} \mathrm{C}$ to $575^{\circ} \mathrm{C}$ for the total combustion of any organic compounds present in the containers. After reaching the maximum temperature, the crucibles remained in heating at $575^{\circ} \mathrm{C}$ for 4 hours. At the end of heating, the crucibles were cooled to room temperature inside a vacuum desiccator, then weighed on an analytical balance (AUW220, Shimadzu). Then, the samples were calcined in which, in each crucible, approximately 0.1 grams of dry biomass were added and the whole (crucible and biomass) was weighed. The samples were taken to the muffle furnace and underwent the same heating process to which the empty crucibles were subjected. After the end of heating and, once cooled, the crucibles were weighed again and the difference between the mass of the post-calcination set and the mass of the empty set represents the amount of ash present.

$$
\mathrm{A}(\%)=\left(\mathrm{M}_{\text {set }}-\mathrm{M}_{\text {emptyset }} / \mathrm{M}_{\text {biomass }}\right) \times 100
$$




\section{Results and discussion}

Table 1 shows the values of specific growth rate $\left(\mu_{\max }\right)$, Biomass Productivity (BP), Lipid Productivity (LP), Proteins Productivity (PP) and Carbohydrate Productivity (CP) in each experiment performed in semicontinuous regime. According to Table 1, the highest value of specific growth rate was reached in experimental condition 6 , using high level of carbon dioxide flow and an intermediate percentage of landfill leachate, both factors that contribute to cell growth [41]. Another study that also evaluated the influence of carbon dioxide on the speed of microalgal growth was developed by Nair, Senthilnathan and Nagendra [42] in which the concentration of $\mathrm{CO}_{2}$ in the feed flow varied between 0.03 and $15 \%$. The results obtained by the authors showed that the highest specific growth rate found was $0.14 \mathrm{~d}^{-1}$ for the experimental conditions that had $\mathrm{CO}_{2}$ percentages equal to $10 \%$ and $15 \%$. This fact corroborates with the results presented in this work, since the highest calculated $\mu_{\max }$ value refers to experimental condition 6 , where carbon dioxide concentration is $15 \%$.

The experimental condition 5 presented the highest productivity in biomass and the second highest productivity in carbohydrate. In addition, the experimental condition 2 presented the highest productivity in lipids and the second highest productivity in proteins.

From Fig. 2a, when the LC factor was adjusted at level 2 (10\%), GP at level 2 (10\%), AF at level 1 (0.15 vvm) and FR at level $2(0.7 \mu \max )$, the Biomass Productivity (BP) had its value maximized. In contrast, when the LC factor was set at level $3(15 \%)$, the GP at level $3(15 \%)$, AF at level $2(0.30 \mathrm{vvm})$ and FR at level $3(0.9 \mu$ max $)$, this response variable has its value minimized. However, as shown in Table 2 (ANOVA), no significant effects of any of the studied factors were observed for the response biomass productivity ( $>0.1$ ), although the landfill leachate seems to be the most influent variable (Figure 2 and Table 2). 
Table 1 Results of Taguchi L9 experimental design performed to evaluate the influence of the factors LC, GP, AF and FR in the response variables, obtained in the semicontinuous regime.

\begin{tabular}{|c|c|c|c|c|c|c|c|c|c|}
\hline Exp. & $(\%)$ & $(\%)$ & $\mathbf{A F} *$ & Vvm & $\begin{array}{c}\mu_{\max } * * \\
\left(d^{-1}\right)\end{array}$ & 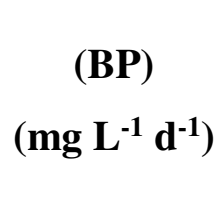 & $\begin{array}{c}(\mathbf{L P}) \\
\left(\mathbf{m g ~ L ^ { - 1 }} \mathbf{d}^{-1}\right)\end{array}$ & $\begin{array}{c}(P P) \\
\left(m g L^{-1} d^{-1}\right)\end{array}$ & $\begin{array}{c}(\mathrm{CP}) \\
\left(\mathrm{mg} \mathbf{L}^{-1} \mathbf{d}^{-1}\right)\end{array}$ \\
\hline 1 & $5(1)$ & Null (1) & $0.15(1)$ & $0.5 \mu_{\max }(1)$ & 0.10 & $77.9 \pm 12.7$ & $5.58 \pm 5.10$ & $47.36 \pm 46.32$ & $3.77 \pm 0.54$ \\
\hline 2 & $5(1)$ & $10(2)$ & $0.30(2)$ & $0.7 \mu_{\max }(2)$ & 0.13 & $64.5 \pm 1.4$ & $11.2 \pm 2.45$ & $54.55 \pm 1.41$ & $3.88 \pm 0.11$ \\
\hline 3 & $5(1)$ & $15(3)$ & $0.45(3)$ & $0.9 \mu_{\max }(3)$ & 0.26 & $74.7 \pm 31.4$ & $4.84 \pm 0.10$ & $55.16 \pm 23.24$ & $2.82 \pm 1.52$ \\
\hline 4 & $10(2)$ & Null (1) & $0.30(2)$ & $0.9 \mu_{\max }(3)$ & 0.08 & $56.8 \pm 5.2$ & $9.13 \pm 0.65$ & $43.26 \pm 1.69$ & $3.60 \pm 0.03$ \\
\hline 5 & $10(2)$ & $10(2)$ & $0.45(3)$ & $0.5 \mu_{\max }(1)$ & 0.15 & $87.7 \pm 1.8$ & $2.22 \pm 0.39$ & $13.59 \pm 3.19$ & $8.02 \pm 4.25$ \\
\hline 6 & $10(2)$ & $15(3)$ & $0.15(1)$ & $0.7 \mu_{\max }(2)$ & 0.47 & $70.1 \pm 13.8$ & $2.38 \pm 1.7$ & $9.49 \pm 7.47$ & $9.57 \pm 4.83$ \\
\hline 7 & $15(3)$ & Null (1) & $0.45(3)$ & $0.7 \mu_{\max }(2)$ & 0.44 & $52.0 \pm 1.5$ & $9.07 \pm 0.15$ & $40.67 \pm 21.25$ & $2.54 \pm 0.29$ \\
\hline 8 & $15(3)$ & $10(2)$ & $0.15(1)$ & $0.9 \mu_{\max }(3)$ & 0.17 & $60.2 \pm 9 ., 3$ & $9.15 \pm 0.88$ & $50.03 \pm 42.53$ & $3.05 \pm 0.13$ \\
\hline 9 & $15(3)$ & $15(3)$ & $0.30(2)$ & $0.5 \mu_{\max }(1)$ & 0.08 & $58.5 \pm 22.7$ & $5.79 \pm 0.20$ & $47.29 \pm 39.58$ & $2.21 \pm 1.40$ \\
\hline
\end{tabular}

where: $\mathrm{LC}=$ landfill leachate concentration; $\mathrm{GP}=\mathrm{CO}_{2}$ percentage added in the gas stream, $\mathrm{AF}=$ aeration flow, $\mathrm{FR}=$ feed flowrate, $\mu$ max $=$ growth rate, $\mathrm{BP}=\mathrm{Biomass}$ Productivity, LP = Lipid Productivity, PP = Protein Productivity and CP = Carbohydrate Productivity.

* Coded values of the studied variables in parenthesis; **Calculated in an initial batch operation, as section 2.2.1 
Fig. 2 Effect graphs of the response variables: Biomass Productivity (a), Lipid Productivity (b), Proteins Productivity (c) and Carbohydrate Productivity (d) in semi-continuous regime.

(a)

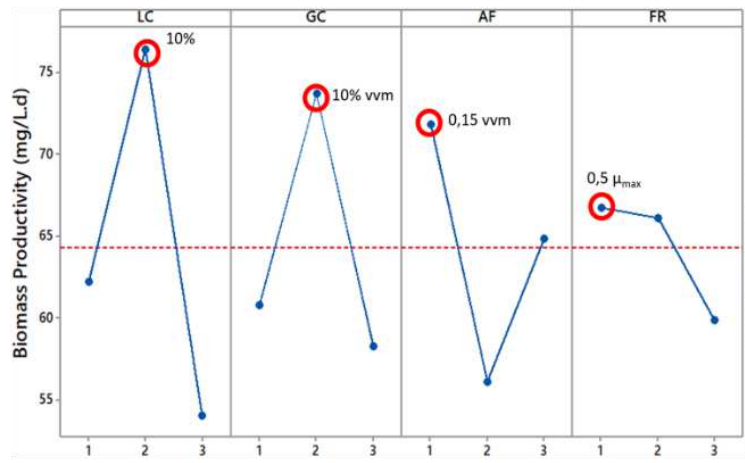

(c)

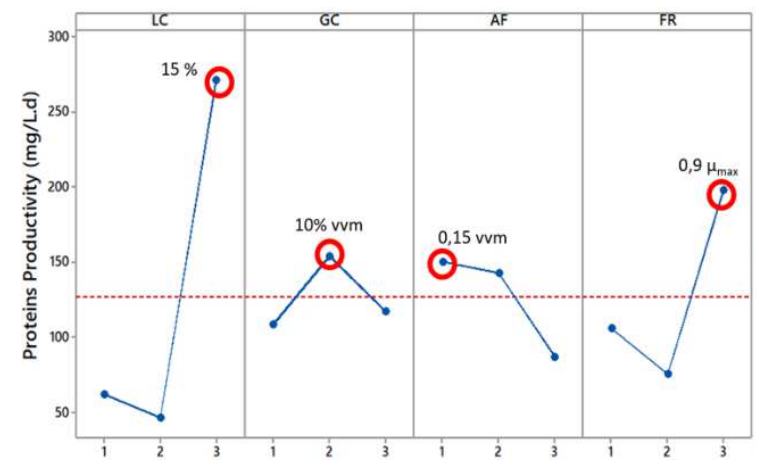

(b)

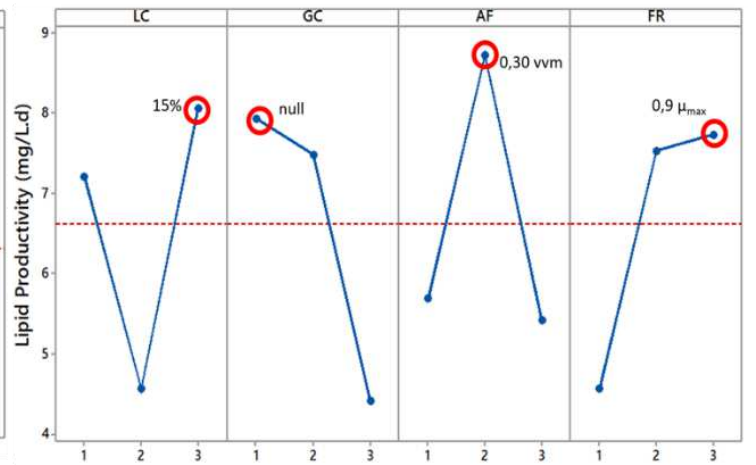

(d)

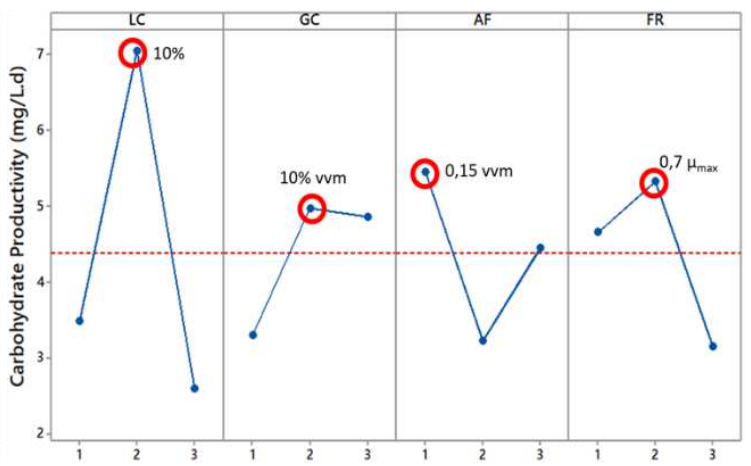

LC - landfill leachate concentration, GP - carbon dioxide percentage added in the gas stream, AF - aeration flow and FR - feed flowrate.

Regarding to lipid productivity, when observing the effects shown in Fig. $2 \mathrm{~b}$, the LC adjusted at level 3 (15\%), the GP factor at level 1 (null), AF at level 2 (0.30 vvm) and FR at level $3(0.9 \mu$ max) resulted in the maximum Lipid Productivity (LP). As shown in Table 2, this response variable was significantly influenced by the factors landfill leachate concentration $(\mathrm{p}<0.1)$, aeration flow $(\mathrm{p}<0.1)$ and feed flowrate $(\mathrm{p}<0.1)$.

On average, the use of high concentration of leachate in the medium favored high lipid productivity (Figure 2). Higher lipid contents in biomass were also observed for high leachate concentrations (experiments 4,7 and 8, Fig. 3). The influence of the culture medium on the lipid productivity has been studied by several authors. In the work developed by Zhao et al. [43] the average levels of lipids were between $14.5-20.8 \%$, using a $10 \%$ dilution of landfill leachate in the culture medium and operating a batch system. Kuo et al. [44] compared the lipid productivity of batch and semi-continuous cultures of the microalgae Chlorella $s p$ in effluents and observed a difference of $30 \%$ between them, with higher productivity in batch mode.

The maximum lipid content obtained in present work was 17.4\% in experiment 7 (Figure 3), under the following conditions: (LC: 15\%, GP: null, AF: 0,45 vvm and FR: $0.7 \mu$ max vvm). In other work, Zhao et al. [45], cultivating Chlorella pyrenoidosa (FACHB-9), reported average levels between 14.5 - 20.8\%, using a 10\% dilution of leachate in the culture medium, which indicates that this level of concentration of slurry contributes to lipid production. In addition, Tighiri and Erkurt [46] found a lipid content of $13.75 \%$ in a mixed culture of microalgae and bacteria, in the proportion of 3:1 of microalgae inoculum, indicating 
that the value of the lipid content obtained in this work is similar to that found in the literature. However, the higher lipid productivity was observed in experiment 2 (Table 1), with also high lipid content in biomass (Figure 3). This result can be also related to the influence of the other factors, such as aeration flow and feed flowrate. Indeed, lipids and proteins are capable of increasing their productivity according to the rate of aeration applied, as it is responsible for the agitation of the culture medium and for the diffusion of nutrients [47]. In the work developed by Serrano-Bermúdez et al. [48], the effect of aeration on the lipid productivity of Botryococcus braunii UTEX 572 was significant. When applied an aeration flow of 0.40 $\mathrm{vvm}$, the productivity of lipids reached values close to $27 \mathrm{mg} \mathrm{L}^{-1} \mathrm{~d}^{-1}$, while for an aeration flow of 1.20 vvm, the productivity of lipids increased to about $40 \mathrm{mg} \mathrm{L}^{-1} \mathrm{~d}^{-1}$, an increase of $48 \%$ by tripling the aeration flow. Regarding to the feed flowrate, in the work developed by Han et al. [49], a feed of $2.2 \mathrm{~mL} \mathrm{~min}^{-1}$ was used in semi-continuous regime cultivation of Chlorella pyrenoidosa in Guillard and Ryther [50] medium in order to evaluate the productivity of lipids, with $\mathrm{pH}$ control in both processes. The authors also studied batch cultivation and observed that, in this case, the lipid productivity reached a maximum value of 82.5 $\mathrm{mg} \mathrm{L}^{-1} \mathrm{~d}^{-1}$, while in the semi-continuous regime, the productivity of lipids reached the value maximum of $115 \mathrm{mg} \mathrm{L}^{-1} \mathrm{~d}^{-1}$, showing an increase of 39\%. Observing the effects graph shown in Fig. 2c, the LC adjusted at level $3(15 \%)$, GP at level 1 (null), AF at level $2(0.30 \mathrm{vvm})$ and FR at level $3(0.9 \mu$ max) resulted in the Protein Productivity (CP) value maximized. According to Table 2, this response variable was significantly influenced by the factors landfill leachate concentration $(\mathrm{p}<0.1)$, aeration flow $(\mathrm{p}<0.1)$ and feed flowrate $(\mathrm{p}<0.1)$.

Eustance et al. [51] studied the influence of aeration flow on the chemical composition of Scenedesmus dimorphous biomass in relation to protein and carbohydrate content. The authors observed that when no aeration was applied in the process, the protein and carbohydrate contents remained between $20 \%$ for proteins and $46 \%$ in carbohydrates. After the application of continuous aeration, these values changed to $27 \%$ in proteins and $42 \%$ in carbohydrates, which exemplifies that the microalgae had greater selectivity for the production of proteins when there was an increase in the aeration flow.

Figure 3 shows the protein content reached a minimum value of $15 \%$ and a maximum value close to $70 \%$ on present work. This high protein content can be observed in microalgae cells that are subjected to culture media under stress conditions, either due to the absence or abundance of certain nutrients [15,52]. E.g., in the work developed by Nordin et al. [53] the cell composition of three microalgae species (Chlorella sp, Scenedesmus $s p$ and Oscillatoria $s p)$ in a culture medium with a high concentration of nitrate $\left(\mathrm{NO}_{3}{ }^{-}\right)$was evaluated. The minimum protein levels found were $36.34 \%$ in Chlorella $s p, 40.54 \%$ in Scenedesmus $s p$ and $45.54 \%$ in Oscillatoria sp. The maximum protein content presented by the authors reached $61.40 \%$ in Oscillatoria $s p$, which accredits this species as a good potential for raw material for the incorporation of products in food industries. In the work carried out by Tagliaferro [54], under cultivation conditions similar to those applied in this work, the protein contents remained close to $30 \%$ and were independent of the landfill leachate concentration, which remained between $5 \%$ and $10 \%$ of the total volume of the reactor. The high protein concentration reached by microalgae in the present work can be interesting for industrial applications, even considering the use of leachate as substrate give restrictions to food applications. Actually, there are nonfood applications of proteins [55-57] and future studies could consider microalgae as raw material in that case. 
Table 2 Analysis of variance (ANOVA) for biomass, lipid, protein and carbohydrate productivity obtained in the semi-continuous regime

Biomass Productivity

\begin{tabular}{cccccc}
\hline Factors & QSF & FD & AQSF & F & P \\
\hline LC & 32.25936 & 2 & 16.12968 & 2.350568 & 0.150899 \\
GP & 23.40507 & 2 & 11.70254 & 1.705403 & 0.235500 \\
AF & 17.76795 & 2 & 8.88397 & 1.294656 & 0.320503 \\
FR & 3.46693 & 2 & 1.73347 & 0.252617 & 0.782094 \\
Residual & 61.75832 & 9 & 6.86204 & & \\
\hline
\end{tabular}

Protein Productivity

\begin{tabular}{cccccc}
\hline Factors & QSF & FD & AQSF & F & P \\
\hline LC & 1337.094 & 2 & 668.5471 & 32.91386 & 0.000073 \\
GP & 45.843 & 2 & 22.9216 & 1.12847 & 0.365341 \\
AF & 210.091 & 2 & 105.0457 & 5.17160 & 0.031968 \\
FR & 476.656 & 2 & 238.3277 & 11.73333 & 0.003109
\end{tabular}

Lipid Productivity

\begin{tabular}{ccccc}
\hline QSF & FD & AQSF & F & p \\
\hline 162.8021 & 2 & 81.40105 & 5.105785 & 0.032965 \\
84.2913 & 2 & 42.14566 & 2.643536 & 0.124982 \\
122.2328 & 2 & 61.11642 & 3.833455 & 0.062480 \\
103.9771 & 2 & 51.98856 & 3.260921 & 0.086069 \\
143.4862 & 9 & 15.94291 & & \\
\hline
\end{tabular}

\section{Carbohydrate Productivity}

\begin{tabular}{ccccc}
\hline QSF & FD & AQSF & F & p \\
\hline 197.4569 & 2 & 98.72845 & 8.327678 & 0.008970 \\
23.4518 & 2 & 11.72592 & 0.989073 & 0.408988 \\
43.2241 & 2 & 21.61204 & 1.822961 & 0.216428 \\
32.1782 & 2 & 16.08909 & 1.357103 & 0.305410 \\
106.6992 & 9 & 11.85546 & &
\end{tabular}

Note: $\mathrm{LC}=$ Landfill Leachate Concentration; $\mathrm{GP}=\mathrm{CO}_{2}$ percentage added in the gas stream; $\mathrm{AF}=$ aeration flow and $\mathrm{FR}=$ feed flowrate; $\mathrm{QSF}=\mathrm{Quadratic}$ Sum of Factors; FD = Degree of Freedom; AQSF = Average Quadratic Sum of Factors. 
Observing the effects graph shown in Fig. 2d, when LC was adjusted at level 2 (10\%), GP at level 2 (10\% $\mathrm{vvm}), \mathrm{AF}$ at level $1(0.15 \mathrm{vvm})$ and the FR at level $2\left(0.7 \mu_{\max }\right)$ the Carbohydrate Productivity (CP) had its value maximized. The maximum value of carbohydrates content was 11.6\%, obtained in Experiment 6 (Figure 3). Also, Table 2 shows that the Landfill leachate concentration $(\mathrm{p}<0.1)$ was the only factor that significantly affected Carbohydrate Productivity. In the work developed by Tagliaferro et al. [58] the highest carbohydrate content found was $15 \%$ in the experimental condition that applied a $10 \%$ dilution of landfill leachate, coinciding with the level of landfill leachate concentration indicated by the effects graph in the present work. In addition, the authors noted that, for lower landfill leachate concentrations, the maximum carbohydrate content was $9 \%$.

As can be seen in Table 2, the percentage of $\mathrm{CO}_{2}$ was not shown to be a significant factor in the studied range for any analyzed productivity. This fact may be related to the diffusion of carbon dioxide in the culture medium. When cultivating microalgae in large quantities, the diffusion of $\mathrm{CO}_{2}$ from the atmosphere or even from other sources becomes a limiting factor for microalgal growth [59] Actually, the diffusion of $\mathrm{CO}_{2}$ in the microalgal culture medium is aided by the formation of bubbles; however, according to Doucha et al. [60] approximately $50 \%$ to $90 \%$ of the carbon dioxide injected in the process returns to the environment. Such waste of $\mathrm{CO}_{2}$ causes a reduction in biomass productivity and an increase in cultivation costs, since about $50 \%$ of the cost of the raw material used in the process is represented by the addition of carbon dioxide [61]. 
Fig. 3 Graphs of cellular chemical composition of biomasses produced in the semi-continuous regime. Experiments conditions according to Table 1.

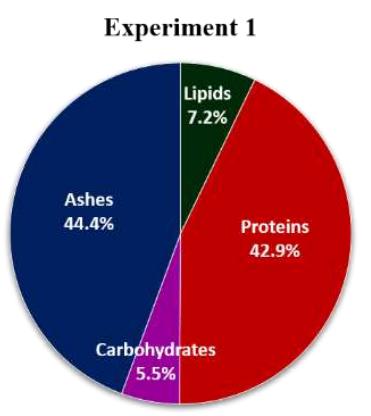

Experiment 4
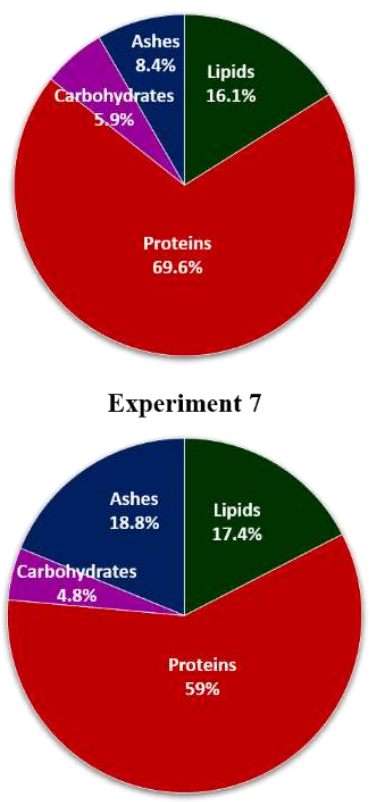

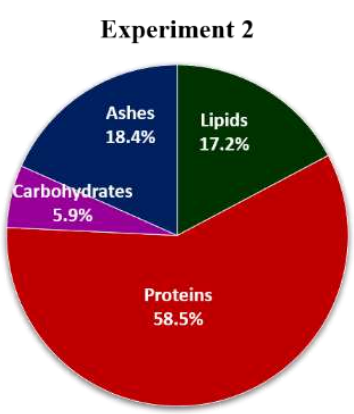

Experiment 5
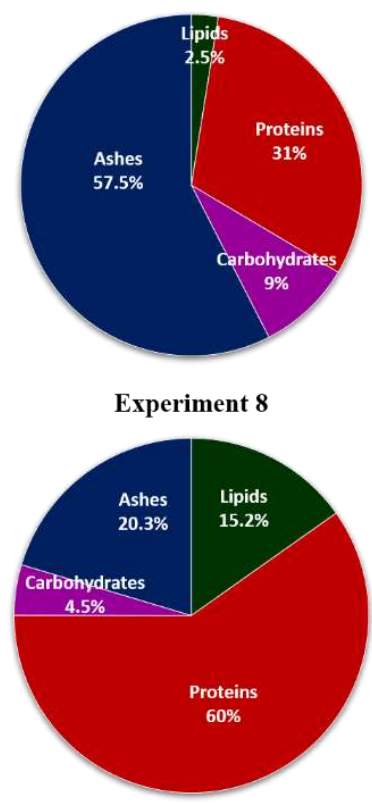

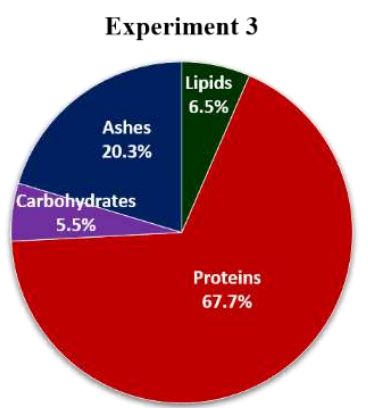

Experiment 6

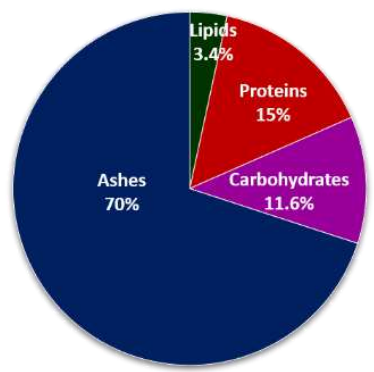

Experiment 9

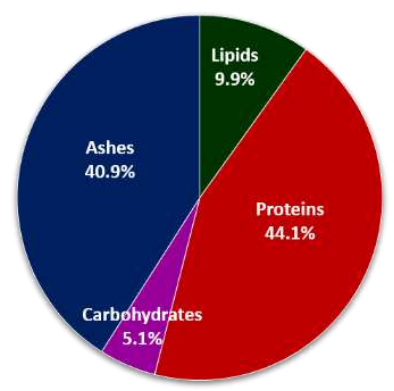

As also shown in Figure 3, ash content varied in a wide range, from $8.4 \%$ to $70 \%$, with maximum value observed by using LC: $10 \%$, GP: $15 \%$, AF: $0,15 \mathrm{vvm}$ and FR: $0.7 \mu$ max. It is known that the ash content refers directly to mineral salts and other components whose boiling temperature is very high, as is the case of metals [62-65], and the values in biomass can vary with species of microalgae, culture conditions, high metallic load present in the leachate [66]. In the work developed by Xu et al. [67], the ash content of the microalgae Chlorella $s p$ was reported as $16.06 \%$ after analysis by four hours of heating at $550{ }^{\circ} \mathrm{C}$. That value was close to those found in experiments 2 and 7 of Figure 3. Ash content variation in literature can also be attributed to different analysis methods. E.g., in the research performed by Cervantes-Urieta et al. [68], the cellular composition of the microalgae Eupyxidicula turris, Trieres mobiliensis and Biddulphia alternans was analyzed and the ash content values found were 50\%,63\% and 70\%, respectively. For ash content analyses, the biomass of the three species of microalgae were subjected to heating in at $600{ }^{\circ} \mathrm{C}$ for two hours and, according to the authors, the low heating time influenced the high ash content. 


\section{Conclusions}

Landfill leachate concentration and aeration flow were crucial factors for all the responses variable analyzed in the present study. The landfill leachate concentration was the factor that most influenced the Biomass Productivity, with higher values at the intermediate level, and also was the only significant factor in Lipid, Proteins and Carbohydrate Productivities. The concentration of carbon dioxide is not a significant factor in the Protein Productivity, as well as it was not significant in any other response variable, with higher values at the intermediate level of aeration flow and high level of landfill leachate concentration and feed flowrate. The applied culture methodology, as well as the culture medium used and the factors studied made it possible to observe that the microalgae cell had greater selectivity for the production of proteins, obtaining a minimum content of $15 \%$ and a maximum content close to $70 \%$.

Acknowledgments The authors would like to thank the financial support of São Paulo Research Foundation (FAPESP, Brazil) through the grants 2014/03244-0 and 2016/23416-6.

\section{References}

1. Markou, G., Iconomou, D., Muylaert, K.: Applying raw poultry litter leachate for the cultivation of Arthrospira platensis and Chlorella vulgaris. Algal Res. 13, 79-84 (2016). https://doi.org/10.1016/j.algal.2015.11.018

2. Souza, M.P., Hoeltz, M., Gressler, P.D., Benitez, L.B., Schneider, R.C.S.: Potential of Microalgal Bioproducts: General Perspectives and Main Challenges. Waste Biomass Valori. 10, 2139-2156 (2019). http://dx.doi.org/10.1007/s12649-018-0253-6

3. Obileke K.C., Onyeaka, H., Omoregbe, O., Makaka, G., Nwokolo, N., Mukumba, P.: Bioenergy from bio-waste: a bibliometric analysis of the trend in scientific research from 1998-2018. Biomass Convers. Bioref. (2020). https://doi.org/10.1007/s13399-020-00832-9

4. Nigam P.S., Singh, A.: Production of liquid biofuels from renewable resources. Progress Energy Combustion Sci. 37, 52-68 (2011). https://doi.org/10.1016/j.pecs.2010.01.003

5. Gumbi, S.T., Mutanda, T., Olaniran, A.O.: Nutrient Removal from Dairy and Poultry Wastewater with Simultaneous Biomass and Biodiesel Production by Chlorella sp. T4 Isolated from a Freshwater Stream in South Africa. Waste Biomass Valori. 7, 0123456789 (2021). https://doi.org/10.1007/s12649-021-01492-0 6. He, Z., Han, W., Jin, W., Yang, J., Gao, S., Li, S., Tu, R., Han, S., Chen, Y., Zhou, X.: Cultivation of Scenedesmus obliquus and Chlorella pyrenoidosa in Municipal Wastewater Using Monochromatic and White LED as Light Sources. Waste Biomass Valori. 7, 0123456789 (2021). https://doi.org/10.1007/s12649-021-01359-4

7. Apandi, N., Mohamed, R.M.S.R., Al-Gheethi, A., Gani, P., Ibrahim, A., Kassim, A.H.M.: Scenedesmus Biomass Productivity and Nutrient Removal from Wet Market Wastewater, A Bio-kinetic Study. Waste Biomass Valori. 10, 783-800 (2019). http://dx.doi.org/10.1007/s12649-018-0313-y

8. Singh, B., Liu, Y., Sharma, Y.C.: Synthesis of biodiesel/bio-oil from microalgae. In: Bux, F. (ed.) Biotechnological Applications of Microalgae Biodiesel and Value-Added Products. pp. 99-112. CRC Press (2013). 
9. Tang, H., Chen, M., Simon, K.Y., Salley, S.O.: Continuous microalgae cultivation in a photobioreactor. Biotechnol. Bioeng. 109, 2468-2474 (2012). https://doi.org/10.1002/bit.24516

10. Guo, X., Yao, L., Huang, Q: Aeration and mass transfer optimization in a rectangular airlift loop photobioreactor for the production of microalgae. Bioresour. Technol. 190, 189-195 (2015). https://doi.org/10.1016/j.biortech.2015.04.077

11. Ramsundar, P., Guldhe, A., Singh, P., Bux, F.: Assessment of municipal wastewaters at various stages of treatment process as potential growth media for Chlorella sorokiniana under different modes of cultivation. Bioresour. Technol. 227, 82-92 (2017). https://doi.org/10.1016/j.biortech.2016.12.037

12. Collota, M., Mabee, C.W., Tomasoni, M. Wastewater and waste $\mathrm{CO} 2$ for sustainable biofuels from microalgae. Algal Res. 29, 12-21 (2018). https://doi.org/10.1016/j.algal.2017.11.013

13. Iasimone F., Panico, A., Felice, V., Fantasma, F., Iorizzi, M., Pirozzi, F.: Effect of light intensity and nutrients supply on microalgae cultivated in urban wastewater: Biomass production, lipids accumulation and settleability characteristics. J. Environ. Manage 223, 1078-1085 (2018). https://doi.org/10.1016/j.jenvman.2018.07.024

14. Tagliaferro G.V., Izário, H.J., Chandel, A.K., Silva, S.S., Silva, M.B., Santos, J.C.: Continuous cultivation of Chlorella minutissima 26a in landfill leachate-based medium using concentric tube airlift photobioreactor. Algal Res. 41, 101549 (2019). https://doi.org/10.1016/j.algal.2019.101549;

15. Brennan L., Owende, P. Biofuels from microalgae-A review of technologies for production, processing, and extractions of biofuels and co-products. Renew. Sustain. Energy Rev. 14, 557-577 (2010). https://doi.org/10.1016/j.rser.2009.10.009

16. Okoro V., Azimov, U., Munoz, J., Hernandez, H.H., Phan, A.N.: Microalgae cultivation and harvesting: Growth performance and use of flocculants - A review. Renew. Sustain. Energy Rev. 115, 109364 (2019). https://doi.org/10.1016/j.rser.2019.109364

17. Park, J., Kumar, G., Bakonyi, P., Peter, J., Nemestóthy, N., Koter, S., Kujawski, W., Bélafi-Bakó, K., Pientka, Z., Munoz, R., Kim, S.H.: Comparative Evaluation of CO2 Fixation of Microalgae Strains at Various CO2 Aeration Conditions. Waste Biomass Valori. 12, 2999-3007 (2021). https://doi.org/10.1007/s12649-020-01226-8

18. Kunjapur A.M., Eldridge, R.B.: Photobioreactor design for commercial biofuel production from microalgae. Ind. Eng. Chem. Research 49, 3516-3526 (2010). https://doi.org/10.1021/ie901459u 19. Prabakaran, G., Moovendhan, M., Arumugam, A., Matharasi, A., Dineshkumar, R., Sampathkumar, P.: Evaluation of Chemical Composition and In Vitro Antiinflammatory Effect of Marine Microalgae Chlorella vulgaris. Waste Biomass Valori. 10, 3263-70 (2019). http://dx.doi.org/10.1007/s12649-018-0370-2

20. Olivieri G., Salatino, P., Marzocchella, A.: Advances in photobioreactors for intensive microalgal production: Configurations, operating strategies and applications. J. Chem. Technol. Biotechnol. 89, 178195 (2014). https://doi.org/10.1002/jctb.4218

21. Tagliaferro G.V., Izário, H.J., Chandel, A.K., Silva, S.S., Silva, M.B., Santos, J.C.: Continuous cultivation of Chlorella minutissima 26a in a tube-cylinder internal-loop airlift photobioreactor to support 3G biorefineries. Ren. Energy 130, 439-445 (2019). https://doi.org/10.1016/j.renene.2018.06.041

22. Azhand N., Sadeghizadeh, A., Rahimi, R.: Effect of superficial gas velocity on $\mathrm{CO} 2$ capture from air by Chlorella vulgaris microalgae in an Airlift photobioreactor with external sparger. J. Environ. Chem. Eng. 
8, 104022 (2020). https://doi.org/10.1016/j.jece.2020.104022

23. Fernandes, F.M., Silva, M.S., Lima, M.A.F., Rocha, A.M., Soares, P.M., Konish, F.: Biodiesel no mundo e no Brasil: situação atual e cenarios futuros. https://www.silvaporto.com.br/wpcontent/uploads/2017/08/BIODIESEL_BRASIL_MUNDO_2015.pdf (2015). Accssed 23 June 2021

24. Iasimone F., Felice, V., Panico, A., Pirozzi, F. Experimental study for the reduction of $\mathrm{CO}_{2}$ emissions in wastewater treatment plant using microalgal cultivation. J. $\mathrm{CO}_{2}$ Util. 22, 1-8 (2017). https://doi.org/10.1016/j.jcou.2017.09.004

25. Zhao X., Zhou, Y., Huang, S., Qiu, D., Schideman, L., Chai, X., Zhao, Y.: Characterization of microalgae-bacteria consortium cultured in landfill leachate for carbon fixation and lipid production. Bioresour. Technol. 156, 322-328 (2014). https://doi.org/10.1016/j.biortech.2013.12.112

26. Caporgno M.P., Taleb, A., Olkiewicz, M., Font, J., Pruvost, J., Legrand, J., Bengoa, C.: Microalgae cultivation in urban wastewater: Nutrient removal and biomass production for biodiesel and methane. Algal Res. 10, 323-239 (2015). https://doi.org/10.1016/j.algal.2015.05.011

27. Hernández-García A., Velásquez-Orta, S.B., Novelo, E., Yánez-Noguez, I., Monge-Ramirez, I., Ledesma, M.T.O.: Wastewater-leachate treatment by microalgae: Biomass, carbohydrate and lipid $\begin{array}{llllll}\text { production. Ecotoxicology } & \text { Environ. } & \text { Safety } & \text { 174, } & 435-444 & \text { (2019). }\end{array}$ https://doi.org/10.1016/j.ecoenv.2019.02.052

28. Singh V., Tiwari, A., Das, M.: Phyco-remediation of industrial waste-water and flue gases with algaldiesel engenderment from micro-algae: A review. Fuel 173, 90-97 (2016). https://doi.org/10.1016/j.fuel.2016.01.031

29. Hu, Z., Qi, Y., Zhao, L., Chen, G.: Interactions Between Microalgae and Microorganisms for Wastewater Remediation and Biofuel Production. Waste Biomass Valori. 10, 3907-3919 (2019). http://dx.doi.org/10.1007/s12649-018-0325-7

30. Ho, S.H., Chen, C.N.N., Lai, Y.Y., Lu, W., Chang, J.S.: Exploring the high lipid production potential of a thermotolerant microalga using statistical optimization and semi-continuous cultivation. Bioresour. Technol. 163, 128-135 (2014). http://dx.doi.org/10.1016/j.biortech.2014.04.028

31. Guillard R.R.L.: Culture of Phytoplankton for Feeding Marine Invertebrates. In: Smith, W.S., Chanley, M.H. (eds.) Culture of Marine Invertebrate Animals, pp.29-60. Springer, Heidelberg (1975). https://doi.org/10.1007/978-1-4615-8714-9_3

32. Bani, A., Gabriel, F., Fernandez, A., D'imporzano, G., Parati, K., Adani, F.: Influence of photobioreactor set-up on the survival of microalgae inoculum. Bioresour Technol 320, 124408 (2021) https://doi.org/10.1016/j.biortech.2020.124408

33. Wan, C., Alam, M.A., Zhao, X.Q., Zhang, X.Y., Guo, S.L., Ho, S.H., Chang, J.S., Bai, F.W.: Current progress and future prospect of microalgal biomass harvest using various flocculation technologies. Bioresour. Technol. 184, 251-257 (2015). http://dx.doi.org/10.1016/j.biortech.2014.11.081

34. Williams S. Official methods of analysis of the Association of official analytical chemists [Internet]. 14th ed. Arlington (Va.): Association of Official Analytical Chemists (1984). Available from: http://lib.ugent.be/catalog/rug01:000071630

35. Bligh, E.G., Dyer, W.J.: A rapid method of total lipid extraction and purification. Can. J. Biochem. Physiol. 37, 911-917 (1959).https://doi.org/10.1139/o59-099

36. Zorn, S.M.F.E., Pedro, G.A., Amaral, M.S., Loures, C.C.A., silva, M.B.: Avaliação dos fatores 
envolvidos na extração de lipídios da biomassa da microalga chlorella minutíssima via solventes. Holos 33, 66-79 (2017). https://doi.org/10.15628/holos.2017.5655

37. Guimarães C.P., Lanfer-marquez, U.M.: Estimativa do teor de fenilalanina em sopas desidratadas instantâneas : importância do nitrogênio de origem não-protéica. Rev. Bras. Cienc. Farm. 41, 365-375 (2005). https://doi.org/10.1590/S1516-93322005000300010

38. Moxley, G., Hang, Y.H.P. More accurate determination of acid-labile carbohydrates in lignocellulose by modified quantitative saccharification. Energ. Fuels 21, 3684-3688 (2007). https://doi.org/10.1021/ef7003893

39. Xia, M.L., Wang, L., Yang, Z.X., Chen, H.Z.: A novel digital color analysis method for rapid glucose detection. Anal. Methods 7, 6654-6663 (2015). https://doi.org/10.1039/C5AY01233C

40. Van Wychen, S., Laurens, L.M.L.: Determination of Total Solids and Ash in Algal Biomas. p. NREL/TP-5100-60956. https:// www.nrel.gov/docs/fy16osti/60956.pdf (2013). Accessed 25 Mat 2021

41. Lin, L., Chan, G.Y.S., Jiang, B. L., Lan, C.Y.: Use of ammoniacal nitrogen tolerant microalgae in landfill leachate treatment. Waste Manag. 27, 1376-1382 (2007). https://doi.org/10.1016/j.wasman.2006.09.001

42. Nair, A.T., Senthilnathan, J., Nagendra, S.M.S. Application of the phycoremediation process for tertiary treatment of landfill leachate and carbon dioxide mitigation. J. Water Process Eng. 28, 322-330 (2019). https://doi.org/10.1016/j.jwpe.2019.02.017

43. Zhao, B., Su, Y., Zhang, Y., Cui, G.: Carbon dioxide fixation and biomass production from combustion

flue gas using energy microalgae. Energy 89, 347-357 (2015). https://doi.org/10.1016/j.energy.2015.05.123

44. Kuo, C.M., Fujian, J., Lin, T.H., Chang, Y.B., Wan, X.H., Lai, J.T., Chang, J.S., Lin, C.S.: Simultaneous microalgal biomass production and $\mathrm{CO}_{2}$ fixation by cultivating Chlorella sp. GD with aquaculture wastewater and boiler flue gas. Bioresour. Technol. 221, 241-250 (2016). https://doi.org/10.1016/j.biortech.2016.09.014

45. Zhao, B., Su, Y., Zhang, Y., Cui, G.: Carbon dioxide fixation and biomass production from combustion flue gas using energy microalgae. Energy 89, 347-357 (2015). http://dx.doi.org/10.1016/j.energy.2015.05.123

46. Tighiri, H.O., Erkurt, E.A.: Biotreatment of landfill leachate by microalgae-bacteria consortium in sequencing batch mode and product utilization. Bioresour. Technol. 286, 121396 (2019). https://doi.org/10.1016/j.biortech.2019.121396

47. Evans, L., Hennigghby, N., Willouet, N., Adeloye, A.J., Skroblin, M., Gutierrez, T.: Effect of organic carbon enrichment on the treatment efficiency of primary settled wastewater by Chlorella vulgaris. Algal Res. 24, 368-377 (2017). https://doi.org/10.1016/j.algal.2017.04.011

48. Serrano-Bermúdez, L.M., Montenegro-Ruíz, L.C., Godoy-Silva, R.D.: Effect of CO2, aeration, irradiance, and photoperiod on biomass and lipid accumulation in a microalga autotrophically cultured and selected from four Colombian-native strains. Bioresour. Technol. Reports 12, 100578 (2020). https://doi.org/10.1016/j.biteb.2020.100578

49. Han, F., Huang, J., Li, Y., Wang, W., Wan, M., Shen, G.: Enhanced lipid productivity of Chlorella pyrenoidosa through the culture strategy of semi-continuous cultivation with nitrogen limitation and $\mathrm{pH}$ 
control by CO2. Bioresour. Technol. 136, 418-424 http://dx.doi.org/10.1016/j.biortech.2013.03.017

50. Guillard, R.R.L., Ryther, J.H.: Studies of marine planktonic diatoms. I. Cyclotella nana Hustedt and Detonula confervacea (Cleve) Gran. Can. J. Microbiol. 8, 229-239, 1962. https://doi.org/10.1139/m62-029 51. Eustance, E., Wray, J.T., Badvipour, S., Sommerfeld, M.R.: The effects of limiting nighttime aeration on productivity and lipid accumulation in Scenedesmus dimorphous. Algal Res. 10, 33-40 (2015). https://doi.org/10.1016/j.algal.2015.04.002

52. Benemann, J.R., Oswald, W.J.: Systems and Economic Analysis of Microalgae Ponds for Conversion of CO2 to Biomass. https://www.osti.gov/servlets/purl/493389. Accessed 23 June 2021

53. Nordin, N., Yusof, N., Samsudin, S.: Biomass Production of Chlorella sp., Scenedesmus sp., and Oscillatoria sp. in Nitrified Landfill Leachate. Waste Biomass Valori. 8, 2301-2311 (2017). https://doi.org/10.1007/s12649-016-9709-8

54. Tagliaferro, G.V. Cultivo da microalga Chlorella minutissima 26a em modo batelada e contí-nuo em fotobiorreatores de tanque de bolhas e airlift: influência do meio de cultivo no crescimento e composição da biomassa. São Paulo Univrsity. https:// teses.usp.br/teses/disponiveis/97/97131/tde-07082018150842/publico/BIT17008_C.pdf (2017). Accessed 25 May 2021

55. Cheng, H.N., Ford, C., Dowd, M.K., He, Z.: Soy and cottonseed protein blends as wood adhesives. Ind. Crops Prod. 85, 324-330 (2016). http://dx.doi.org/10.1016/j.indcrop.2015.12.024

56. Bandara, N., Chen, L., Wu, J.: Adhesive properties of modified triticale distillers grain proteins. Int. J. Adhes. Adhes. 44, 122-129 (2013). http://dx.doi.org/10.1016/j.ijadhadh.2013.02.014

57. Barone, J.R., Schmidt, W.F.: Nonfood applications of proteinaceous renewable materials. J. Chem. Educ. 83, 1003-1009 (2006). https://doi.org/10.1021/ed083p1003

58. Tagliaferro, G.V., Izário, H.J.F., , Filho I, Chandel, A.K., Silva, S.S., Silva, M.B., Santos, J.C.: Continuous cultivation of Chlorella minutissima 26a in a tube-cylinder internal-loop airlift photobioreactor to support 3G biorefineries. Renew. Energy 130, 439-45 (2019). https://doi.org/10.1016/j.renene.2018.06.041

59. Lundquist, T., Woertz, I., Quinn, N., Benemann, J.: A Realistic Technology and Engineering Assessment of Algae Biofuel Production. Energy Biosciences Institute. https://www.researchgate.net/publication/47654202_A_Realistic_Technology_and_Engineering_Assess ment_of_Algae_Biofuel_Production\#fullTextFileContent (2010). Accessed 25 May 2021

60. Doucha, J., Straka, F., Lívansky, K.: Utilization of flue gas for cultivation of microalgae (Chlorella sp.) in an outdoor open thin-layer photobioreactor. J. Appl. Phycology 17, 403-412 (2005). https://doi.org/10.1007/s10811-005-8701-7

61. Acién, F.G., Fernández, J.M., Magán, J.J., Molina, E.: Production cost of a real microalgae production plant and strategies to reduce it. Biotechnol. Adv. 30, 1344-1353 (2012). https://doi.org/10.1016/j.biotechadv.2012.02.005

62. Mohammady, N., El-Sayed, H., Fakhry, E., Taha, H., Mohamed, J., Mahmoud, N., Abdelsalam, B.: Locally isolated microalgae as a source of biodiesel and by-products: an integral study of Med-Algae Project. Int. J. Chem. Concepts 1, 94-102 (2015). http://www.iglobaljournal.com/wpcontent/uploads/2014/08/4.-Bhattacharjee-et-al.-IGJPS-2014.pdf\%5Cnhttp://dx.doi.org/10.1007/s13410- 
013-0125-3\%5Cnhttp://dx.doi.org/10.1007/s12562-012-0552-

y\%5Cnhttp://dx.doi.org/10.1007/BF02976957\%5Cnhttp://dx.doi.org/10.1

63. Sandoval, M.A., María, R., Flores, F., Ricardo, E., Narváez, A., Villada, J.L.: Phototrophic culture of Chlorella sp. using charcoal ash as an inorganic nutrient source. Algal Res. 11, 368-374 (2015). https://doi.org/10.1016/j.algal.2015.07.008

64. Cancela, A., Álvarez, X., Sánchez, A., Ortiz, L., Somoza, L.: Microalgae cultivation and harvesting for $\begin{array}{lllllll}\text { bioenergy production. } & \text { Biores. Technol. Reports } & \mathbf{8}, & 100333 & \text { (2019). }\end{array}$ https://doi.org/10.1016/j.biteb.2019.100333

65. Souza, R.A.S., Corrêa, F.M.P.S., Gallego, A.G., Neto, A.M.P.: Semi-quantitative determination of ash element content for freeze-dried, defatted, sulfated and pyrolysed biomass of Scenedesmus sp. Biotechnol. Biofuels 13, 1-13 (2020). https://doi.org/10.1186/s13068-020-01699-8

66. Phukan, M.M., Chutia, R.S., Konwar, B.K., Kataki, R.: Microalgae Chlorella as a potential bio-energy feedstock. Appl. Energy 88, 3307-3312 (2011). https://doi.org/10.1016/j.apenergy.2010.11.026

67. Xu, D., Wang, Y., Lin, G., Guo, S., Wang, S., Wu, Z.: Co-hydrothermal liquefaction of microalgae and sewage sludge in subcritical water: Ash effects on bio-oil production. Renew. Energy 138, 1143-115 (2019). https://doi.org/10.1016/j.renene.2019.02.020

68. Cervantes-Urieta, V.A., Pérez-Castro, D., Galeana-Parra, M.A., Ramírez-Fuentes, E., Trujillo-Tapia, M.N.: Cultivo y composición bioquímica de diatomeas marinas (Bacillariophyta) de la Bahía de Santa Lucía. Gayana. Botánica 77, 11-22 (2020). http://dx.doi.org/10.4067/S0717-66432020000100011 